\title{
Priority Criteria and Alternatives for University Business Incubators in the Entrepreneurial Process in Mexico
}

\author{
Lizbeth Martínez Ramírez*, Jaime Muñoz***
}

The Schumpeterian theory of economic development establishes the innovation process as a key factor for entrepreneurship. Nevertheless, not every entrepreneur exercises innovation and not every innovation leads to entrepreneurship. University Business Incubators (UBIs) have been considered as the main factor for entrepreneurial process in which if innovation takes place, the perspective of economic success becomes wide open. Currently, UBIs are typified and considered around the world as guides in the process of entrepreneurship; one of their objectives is the creation of startups that can eventually consolidate in the market. The aim of this work is to identify by means of the Analytic Hierarchy Process (AHP) the priority of UBIs performance criteria on the basis of the main levels of impacts the literature remarks on: a) economic action, b) National Development Plan and/or c) scientific action. These criteria are related with four characteristic UBIs functions: $i)$ provision of means of production, ii) strengthening entrepreneurship culture, iii) bonding with the market to generate a base of future firms, and, iv) creating pull effect. The hypothesis of this work is that UBIs classification not only allows for identifying their main characteristics but it also points toward a normative application of criteria and alternatives of performance, in order to reach the objective of creating and fostering solid and stable enterprises, no matter the sponsoring university characteristics. We tested it by analyzing the three most important Mexican UBIs. The results show that although the analyzed UBIs are a specific type of business incubators, their criteria and alternatives of performance differ among them.

Keywords: AHP, business incubators, innovation, entrepreneurship.

Submitted: 20.06.2015 | Accepted: 1.10.2015

\section{Priorytetowe kryteria i alternatywy stosowane przez akademickie inkubatory przedsiębiorczości w procesie przedsiębiorczym w Meksyku}

Wedtug teorii rozwoju gospodarczego Schumpetera proces innowacyjny jest czynnikiem o kluczowym znaczeniu dla przedsiębiorczości. Nie wszyscy przedsiębiorcy dokonuja jednak innowacji $i$ nie wszystkie innowacje warunkuja przedsiębiorczość. Akademickie inkubatory przedsiębiorczości (AIP) zostaty uznane za główny czynnik procesu przedsiębiorczego, w ramach którego - jeśli dojdzie do innowacji - otwieraja się szerokie perspektywy sukcesu gospodarczego. Obecnie na świecie AIP sa zaliczane do kategorii podmiotów wyznaczających

\footnotetext{
* Lizbeth Martínez Ramírez - PhD Student in Economics Sciences, Universidad Autónoma Metropolitana.

Adres do korespondencji: Economics Sciences, Universidad Autónoma Metropolitana, e-mail: martinez7lizbeth@gmail.com.

** Jaime Muñoz - Researcher Professor, PhD in Economics, Autonomous Metropolitan University. Adres do korespondencji: Autonomous Metropolitan University, e-mail: jaimemunozflores@gmail.com.
} 
kierunki $w$ procesie przedsiębiorczym. Jednym $z$ ich celów jest tworzenie przedsiębiorstw, które ostatecznie moga utrwalić swoja pozycję na rynku. Artykut ma na celu określenie za pomoca metody AHP hierarchii kryteriów wydajności AIP $z$ wykorzystaniem wymienionych $w$ literaturze różnych poziomów wptywu. Sa to: a) działania gospodarcze, b) narodowy plan rozwoju oraz c) dziatania naukowe. Kryteria te wiaża się z czterema charakterystycznymi funkcjami AIP: i) dostarczanie środków produkcji, ii) rozwijanie kultury przedsiębiorczości, iii) nawiazywanie kontaktów z rynkiem w celu utworzenia bazy przyszlych przedsiębiorstw oraz iv) wywolywanie „efektu przyciagania”. Hipoteza postawiona $w$ artykule głosi, że klasyfikacja AIP nie tylko umożliwia określenie ich głównych cech, lecz również wskazuje normatywne zastosowanie kryteriów i alternatywnych sposobów osiagnięcia wydajności w celu tworzenia $i$ wspierania rozwoju solidnych $i$ stabilnych przedsiębiorstw niezaleznie od cech uczelni sponsorujacej. Weryfikacji tej hipotezy dokonano na bazie analizy trzech najważniejszych meksykańskich AIP. Wyniki wskazuja, że chociaż badane AIP stanowia specyficzny rodzaj inkubatorów przedsiębiorczości, różnia się pod względem stosowanych kryteriów i alternatywnych sposobów osiagania wydajności.

Słowa kluczowe: AHP, inkubatory przedsiębiorczości, innowacje, przedsiębiorczość.

Nadesłany: 20.06.2015 | Zaakceptowany do druku: 1.10.2015

JEL: O31, O32

\section{Introduction}

Recently, innovation has been viewed as a key factor for the entrepreneurial process which requires help from other actors in the innovation system (Aernoudt, 2004). Although it is known that the entrepreneurial success depends on many aspects of the context it is developed in (Autio et. al, 2014), there is a world tendency of supporting entrepreneurship by different organizations in order to aid the entrepreneurs in achieving success (Radosevic \& Myrzakhmet, 2009). Examples of such organizations are the University Business Incubators (UBIs) which were classified by Carayannis \& Von Zedtwitz (2005) among others types of business incubators according to their objectives. Mian (1997) declared that UBIs share similar characteristics but also have some unique features, while Bollingtoft and Ulhoi (2005) postulated that different incubators have different priorities. The aim of this work is to identify the UBIs performance criteria and the level of impact at which they use alternatives to attain their objectives. The hypothesis of this work is that UBIs classification not only allows for identifying their main characteristics but also points toward a normative application of criteria and alternatives of performance, in order to reach the objective of creating and fostering solid and stable enterprises, no matter the sponsoring university char- acteristics. This is assessed among the three most important Mexican UBIs (Díaz, 2015) by means of the Analytic Hierarchy Process (AHP) with established criteria of performance and alternatives to satisfy them. The criteria included in the AHP model of this work were established on the main levels of impacts the literature remarks on: a) economic action, b) National Development Plan and/or c) scientific action, (Aernoudt, 2004), (OECD, 2013), and as alternatives, four UBIs functions were considered: i) provision of means of production, ii) strengthening entrepreneurship culture, iii) bonding with the market to generate a base of future firms, and, iv) creating pull effect (Aerts, Matthyssens, \& Vandenbempt, 2007), (Bergerk \& Norrman, 2008), (Brunnel, Tiago, \& Clarysse, 2012).

The main contribution of this work is to identify the criteria of performance that UBIs apply from the stand point of the relevance of interaction between the aforementioned alternatives. The manuscript is organized as follows. The next section is a review of the literature about innovation and entrepreneurship, UBIs and the AHP. Section 3 describes the analyzed UBIs and the criteria and alternatives used to identify their performance priorities. Section 4 presents the results of the AHP model applied, section 5 is the discussion and in the last section conclusions are presented. 


\section{Literature Review}

\subsection{Innovation}

Innovation is seen as the panacea for competing successfully in today's global marketplace (Carayannis \& Von Zedtwitz, 2005); the study of innovation as a key factor of economic development has increased relevance (Skuras, Tsegenidi, \& Tsekouras, 2008). Economic theory has highlighted the important role of innovation for the growth of regions and countries (Wong, Ho, \& Autio, 2005); one example of this is the European Union, which aspires to become the most competitive economy in the world and intends to achieve this aim through innovation (Commission of the European Communities, 2000) in (Aerts, Matthyssens, \& Vandenbempt, 2007).

Innovation as a key factor for enterprise success has been widely recognized around the world. Disregarding their size or other aspects (Lee, Park, Yoon, \& Park, 2009), (Radas \& Bozié, 2009), innovation led the companies to find crucial changes for their success and survival; without innovation the economic failure is inevitable (Schumpeter, 1934).

According to the OECD, "innovation concerns changes planned in the company activities in order to improve its performance" (OECD, 2013). The types of innovation refer to products, processes, markets and organizational innovations. The difference among innovations on the basis of what is "new" or what is "radical" depends on the extent of the change (Schumpeter, 1934). The prerequisite of any innovation is the generation of new knowledge or alternatively a combination of existing knowledge and ways of business innovation (Drucker, 1985). Swann (2009) argues that innovations arise from inventions and lead to a process whose purpose is the generation of wealth; he also establishes that there is a difference between innovation and invention, assuming the economic distinction generated: invention is the generation of new ideas that can culminate in patents, for example, but they could not be commercialized, while innovation involves commercial exploitation of such inventions and this leads to the creation of wealth.

The academic network of innovation emerged in the 1980s. Lundvall (1988, 1992), Freeman (1987, 2000), and Nelson (1982), among others, emphasized the holistic nature of innovation. They remarked on the external relations and the complex interaction of the institutional environment as important factors which guide and facilitate the performance of economic agents who are involved in entrepreneurship; nowadays innovation has been strongly associated with entrepreneurship (Autio et. al., 2014) as "the means by which the entrepreneur either creates new wealth-producing resources or endows existing resources with enhanced potential for creating wealth" (Drucker, 1985).

\subsection{Entrepreneurship}

The Commission of the European Communities (2003) postulates that "Entrepreneurship is the mindset and process to create and develop economic activity by blending risk-taking, creativity and/or innovation with sound management, within a new or an existing organization". Although entrepreneurship is present around the world, it changes according to the place, period and context (Brunnel, Tiago, \& Clarysse, 2012). Entrepreneurs reflect the characteristics of the place and the time at which they develop (Pierre-André \& Molina, 2012). According to this, there are two kinds of entrepreneurship: a) entrepreneurship driven by a subsistence necessity and b) entrepreneurship driven by a development necessity (Evans \& Leighton, 1989), (Wong, Ho, \& Autio, 2005).

a) Entrepreneurship driven by a subsistence necessity is related to developing economies where some people start a non-innovation business in order to obtain resources for satisfying basic needs. Usually, those people do not have a formal job, so they have to perform an activity in order to obtain low amounts of money every day with a short-term perspective and without a specific business plan for the long term. On a macroeconomic level, it causes the emergence of an economic system characterized by informality and it is related with the "refuge effect" discovered by Evans and Leighton (1989) and Reynolds et al. (1994).

b) Entrepreneurship driven by a development necessity is related to developed economies whose main objective is economic growth, and this kind of entrepreneurship is based on innovation (Wong, Ho, \& Autio, 2005); enterprise creation usually has a long-term perspective and a well-constructed business plan. 
"The concept of entrepreneurship generally refers to enterprising individuals who display the readiness to take risks with new or innovative ideas to generate new products or services" (OECD, 2008), but according to the OECD (2008), the economic literature has considered the entrepreneur as a bearer of uncertainty (Cantillon, 1755), as a speculator (von Mises, 1949), as a coordinator and arbitrageur (Walras, 1954), (Kirzner, 1973) and as an innovator (Schumpeter, 1934). After Schumpeter, the entrepreneur has been considered an economic agent who identifies and exploits opportunities within the economic system and he involves endowed existing resources with new wealth-produce capacity (Penrose, 1959), (Drucker, 1985), (Lumpkin \& Dess, 1996), (Shane \& Venkataraman, 2000).

Recently in developing economies as well as developed economies, entrepreneurship has been supported by intermediaries that engage successful entrepreneurs (Lee, Park, Yoon, \& Park, 2009); an example of this are the UBIs. Governments around the world have also adopted support innovation policies and assisted high technology startups; it means there is a tendency to support entrepreneurship driven by the development necessity (Wong, Ho, \& Autio, 2005).

The importance of cooperation with other organizations rather than the selfsufficiency of individual agents in the entrepreneurial process has been recognized in innovation systems and it reflects the fact that enterprises in general require network support and eventually that of intermediaries who strengthen the early stages of development as UBIs do.

By bonding the concept of innovation and entrepreneurship, it could be said that innovation is closely related to novelties and scientific discoveries, while entrepreneurship is closely related to the environment required to put those discoveries in the market. Entrepreneurship is a dynamic process that concerns the environment and links discoveries and satisfaction of market necessities. Entrepreneurs recognize and assess opportunities, risk, organization and assume liability for economic results of innovations.

Business incubators are considered instruments of public policies for the promotion of innovation, entrepreneurship and the creation of new small businesses, offering technical and management support through internal efforts or through connections to external cooperative networks (Schwartz and Hornych, 2010, cited in Azevedo \& Chiappetta, 2012); without the correct coordination of resources, networks and management knowledge, entrepreneurs may find barriers to success (Sá \& Lee, 2012), which is one of the reasons why the innovation system stresses the contributions of different organizations in the innovation process (Howells, 2006), and more incubators are strongly considered to be an instrument to promote innovation (Aernoudt, 2004). This work focuses on "entrepreneurship" oriented universities (Etzkowitz \& Leydesdorff, 2000) through the classified UBIs (Carayannis \& Von Zedtwitz, 2005) described below.

\subsection{University Business Incubators (UBIs)}

Currently the literature establishes a general definition of business incubators as entities which provide small businesses with resources that improve their chances of foundation and survival (Radosevic \& Myrzakhmet, 2009), (Lee \& Osteryoung, 2004), (Somsuk \& Laosirihongthong, 2014). The typical incubator services are office services, business assistance, access to capital and access to business networks (Grimaldi \& Grandi, 2005), (Sá \& Lee, 2012), (Aerts, Matthyssens, \& Vandenbempt, 2007). According to the OECD (1999), the main objectives of the programs of business incubators are: reducing unemployment; creating strong companies with high survival rate; fostering local and regional economy; expanding business networks and infrastructure; commercializing university discoveries; strengthening the technology development.

Business incubators are considered as part of the innovation systems where the creation, selection and transformation of knowledge takes place in a complex matrix of interactions between different actors (enterprises, universities, researchers, financial institutions) that are diversified economically, institutionally, socially, politically, culturally and geographically (Azevedo \& Chiappetta, 2012).

Although the literature establishes general definitions of business incubators, some authors have attempted to classify business incubators and they propose that the characteristics and objectives of busi- 
ness incubators differ according to the types of incubators (Aernoudt, 2004), (Barbero et al., 2012), (Carayannis \& Von Zedtwitz, 2005), (Mian, 1997). The type of business incubator focused on in this work is the one proposed by (Carayannis \& Von Zedtwitz, 2005), namely UBIs which are identified as a strong instrument to promote innovation and entrepreneurship (Aerts, 2007), (Autio et al., 2014), (Sá \& Lee, 2012), (Somsuk \& Laosirihongthong, 2014). In the literature on UBIs, the issue of enabling factor identification has been hardly studied (Keizer, Dijkstra, \& Halman, 2002), (Lee \& Osteryoung, 2004), (Somsuk \& Laosirihongthong, 2014); nevertheless, due to different statements about UBIs, it is important to foster the identification of the criteria of performance that UBIs consider in order to reach their objectives. As a contribution to this issue, this work stresses this identification by means of the AHP described in the next subsection:

\subsection{Analytic Hierarchy Process (AHP)}

The Analytic Hierarchy Process (AHP) emerged at the beginning of the 1980s as a methodological resource that allows combining qualitative and quantitative information. The AHP is based on the definition of multiple criteria as well as the identification and weighting of alternatives that best meet those criteria to achieve the objective. Given its capacity to combine objectives, multiple criteria and multiple alternatives, even with subjective judgments, the AHP is widely applicable for decision-making under uncertainty.

Figure 1. Schematic objective, criteria and multiple alternatives representation

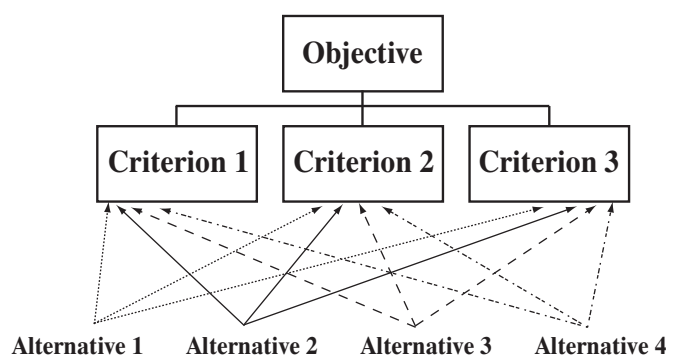

Source: own elaboration.

The AHP considers subjective judgments based on the experience of the decision makers, and such judgments are combined with the qualitative and quan- titative information available, resulting in the prioritization of the existing alternatives tested following the principle of consistency. In AHP models the available information (qualitative and quantitative) is combined with value judgments based on the knowledge and expertise of the decision makers. From this combination the relevance of each of the criteria is determined in relative terms.

Figure 2. Example of relative criteria importance

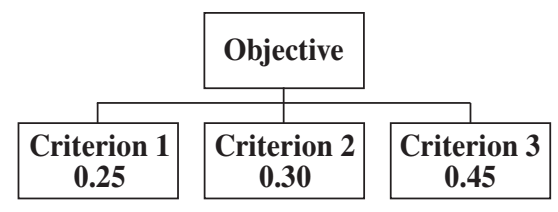

Source: own elaboration.

The AHP methodology sets up a pairwise comparison of existing alternatives by considering compliance of each alternative with respect to each criterion. At this stage of the process, the series of transverse and longitudinal data as well as all available qualitative information could be exploited for the establishment of value judgments.

Table 1. Matrix of pairwise comparison

\begin{tabular}{|l|c|c|c|}
\hline & $\begin{array}{c}\text { Criterion } \\
\mathbf{1}\end{array}$ & $\begin{array}{c}\text { Criterion } \\
\mathbf{2}\end{array}$ & $\begin{array}{c}\text { Criterion } \\
\mathbf{3}\end{array}$ \\
\hline Criterion 1 & 1 & 1 & 0.3 \\
\hline Criterion 2 & 1 & 1 & 1.0 \\
\hline Criterion 3 & 3 & 1 & 1.0 \\
\hline
\end{tabular}

Source: own elaboration.

The AHP calculates, through matrix algebra, the corresponding vector to the ranking of alternatives with the integral combination of relative relevance to each criteria, obtaining the global priorities to achieve the objective. The notation is:

- For i given objective $\mathbf{i}=1,2, \ldots . \mathbf{m}$, we resolve the Wi weights

- For each objective I, we compare the $\mathbf{j}=1,2, \ldots \ldots . \mathbf{n}$ alternatives and we resolve the Wij weights in respect of the objective $\mathbf{i}$

- We resolve the final $\mathbf{W j}$ weight in respect of the objective, thus

$\mathbf{W j}=w 1 j w 1+w 2 j w 2+\ldots+w m j w m$ 
Table 2. Objective, criteria and alternatives of the applied AHP Model

\begin{tabular}{|c|c|c|c|}
\hline Objective & Criteria & Level of impact & Alternatives \\
\hline \multirow{4}{*}{$\begin{array}{l}\text { Identify } \\
\text { the priority } \\
\text { of UBIs } \\
\text { performance }\end{array}$} & a) Economic action & Regional & $\begin{array}{l}\text { i) Provision of means of } \\
\text { production }\end{array}$ \\
\hline & $\begin{array}{l}\text { b) National Development } \\
\text { Plan }\end{array}$ & National & $\begin{array}{l}\text { ii) Strengthening entrepreneurship } \\
\text { culture }\end{array}$ \\
\hline & \multirow[t]{2}{*}{ c) Scientific action } & \multirow[t]{2}{*}{$\begin{array}{l}\text { Particular or } \\
\text { institutional }\end{array}$} & $\begin{array}{l}\text { iii) Bonding with the market to } \\
\text { generate a base of future firms }\end{array}$ \\
\hline & & & iv) Creating pull effect \\
\hline
\end{tabular}

Source: own elaboration.

The alternatives are in descending order according to $\mathbf{W j}$ and the biggest value indicates the best alternative.

Figure 3. Scheme of multicriteria and multialternatives with quantified relevance

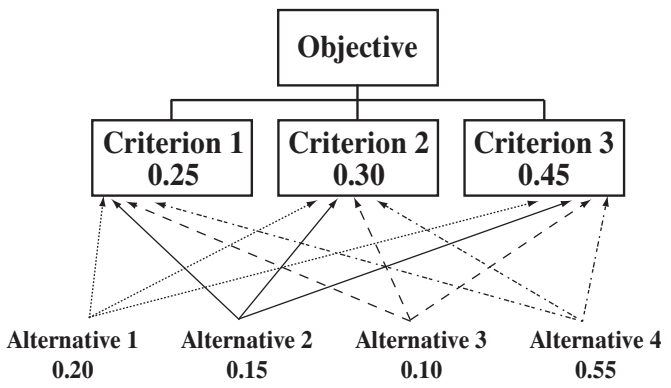

Source: own elaboration.

\section{Description of UBIs, criteria and alternatives of the analysis}

In order to reach the objective of this work, we analyzed the three most important Mexican UBIs pointed by (Díaz, 2015) by identifying the priority of performance on the basis of three criteria the literature remarks on: a) economic action, b) National Development Plan, and, c) scientific action (institutional results); as well as four alternatives: i) provision of means of production, ii) strengthening entrepreneurship culture, iii) bonding with the market to generate a base of future firms, and, iv) creating pull effect.

\subsection{UBIs}

The AHP model was applied to UBIs: IPN, UNAM and ITESM, which are considered the most important UBIs in Mexico (Díaz, 2015). The IPN is recognized for technological orientation and it has national presence; nevertheless, it has only one principal UBI located in Mexico City but it is a highly recognized UBI among the researchers and the Mexican network of startup creation. Although the UNAM is the biggest university in Mexico, its UBI is relatively new It was established in 2009 and currently receives projects in nine UBI offices in Mexico City. The ITESM is a private university known as the strongest entrepreneurial university; this institution brings together a group of UBIs which are located in different Mexican states. The three analyzed institutions are recognized by INADEM ${ }^{1}$ and they have the objective of startup creation (Díaz, 2015).

The AHP model is based on the criteria and alternatives summarized in Table 2.

\subsection{Criteria:}

a) Economic action. This criterion is related to the impact at the regional level (Aerts, Matthyssens, \& Vandenbempt, 2007), (Grimaldi \& Grandi, 2005). It is considered on the basis that the entrepreneurial oriented universities prove to be key for regional economic development, going beyond the provision of graduates and research (Etzkowitz \& Leydesdorff, 2000).

b) National Development Plan (NDP). It is a document where the government stipulates its objectives (OECD, 2013) and which states that all the national institutions have to be aligned with the main national objectives. The Mexican NPD 2013-2018 establishes that the development and economic growth in Mexico is an integral framework in which universities take part; this is the reason for considering the NPD as a criterion of UBIs performance. 
Table 3. Saaty's scale

\begin{tabular}{|c|c|c|}
\hline Intensity & Level of importance & Meaning \\
\hline 1 & Equal & Two activities contribute in equal way to the objective \\
\hline 3 & Moderate & $\begin{array}{l}\text { The experience and the judge favor slightly one activity } \\
\text { over the other }\end{array}$ \\
\hline 5 & Strong & $\begin{array}{l}\text { The experience and the judge favor strongly one activity } \\
\text { over the other }\end{array}$ \\
\hline 7 & Very strong & One activity is much favored over the other \\
\hline 9 & Extreme & $\begin{array}{l}\text { The evidence of favoring one activity over the other is } \\
\text { absolute and totally clear }\end{array}$ \\
\hline $2,4,6,8$ & Intermediate values & Adjacent values \\
\hline Reciprocal & aij $=1 /$ aij & Hypothesis of the method \\
\hline
\end{tabular}

Source: own elaboration based on (Saaty, 1977).

Table 4. Example of pairwise comparison

\begin{tabular}{|c|c|c|c|c|c|c|c|c|c|c|c|c|c|c|c|c|}
\hline \multicolumn{17}{|c|}{ Comparison of criteria } \\
\hline Criterion $\downarrow$ vs. & 4 & & & & & & & & & & & & & & & Criterion $\downarrow$ \\
\hline Economic action & 9 & 8 & 7 & 6 & $5 \mid 4$ & 3 & 2 & 1 & 2 & & 4 & 6 & 7 & 8 & 9 & National Development Plan \\
\hline
\end{tabular}

Source: own elaboration.

c) Scientific action. This criterion identifies the promotion of science generated as contributions to the mission of the university (Mian, 1997). The UBI acts in order to have a good impact focused on its sponsoring institution (Grimaldi \& Grandi, 2005), (Carayannis \& Gonzalez, 2003).

\subsection{Alternatives:}

i) Provision of means of production. The UBI offers to its community resources related with human and financial capital and infrastructure as office services, business assistance, access to capital and access to business networks (Bergerk \& Norrman, 2008), (Grimaldi \& Grandi, 2005)

ii) Strengthening entrepreneurship culture. The UBI acts in order to convince the scientists to put their ideas into the market (Aerts, Matthyssens, \& Vandenbempt, 2007), (Grimaldi\& Grandi, 2005)

iii) Bonding with the market to generate a base of future firms. The UBI introduces a startup into a public or private organization which takes into account the startups in its value chain. (OECD, 2013) iv) Creating pull effect. For the UBI it is important to create a complete global effect in which big enterprises help startups to enter the market (Aerts, Matthyssens, \& Vandenbempt, 2007), (Keizer, Dijkstra, \& Halman, 2002)

\subsection{Assessment}

In order to obtain the judgments of the experts in UBIs ${ }^{2}$, they defined, by pairwise comparison, the importance of each criterion relative to the others, as well as each alternative relative to the others, in reference to each criterion, according to Saaty's scale (1977) (Table 3).

Example: Mark with ${ }^{\times}$the level of importance of criterion "Economic action" versus the criterion "National Development Plan" (Table 4).

The example shows that the criterion "National Development Plan" is strongly more important than the criterion "Economic action". The following pairwise comparisons were used to get the assessment of the experts; each group of pairwise comparisons represents a support matrix of the final prioritization (Table 5, Table 6). 


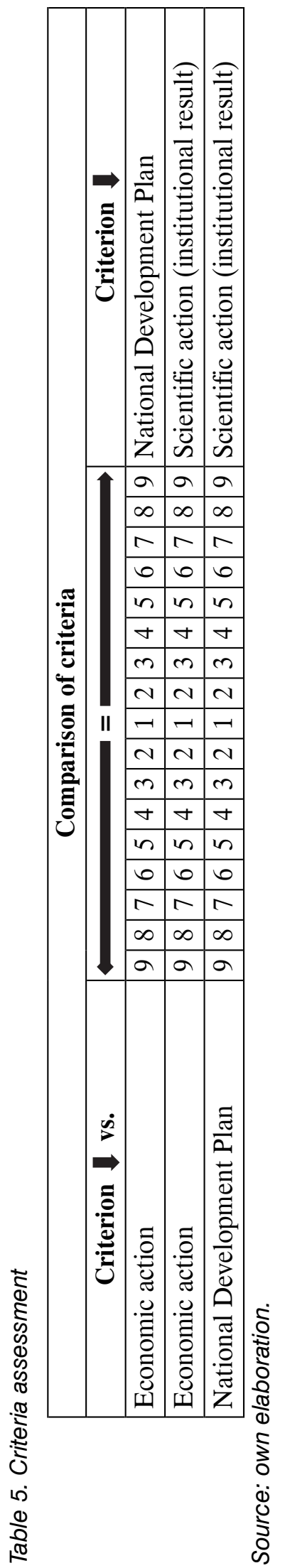

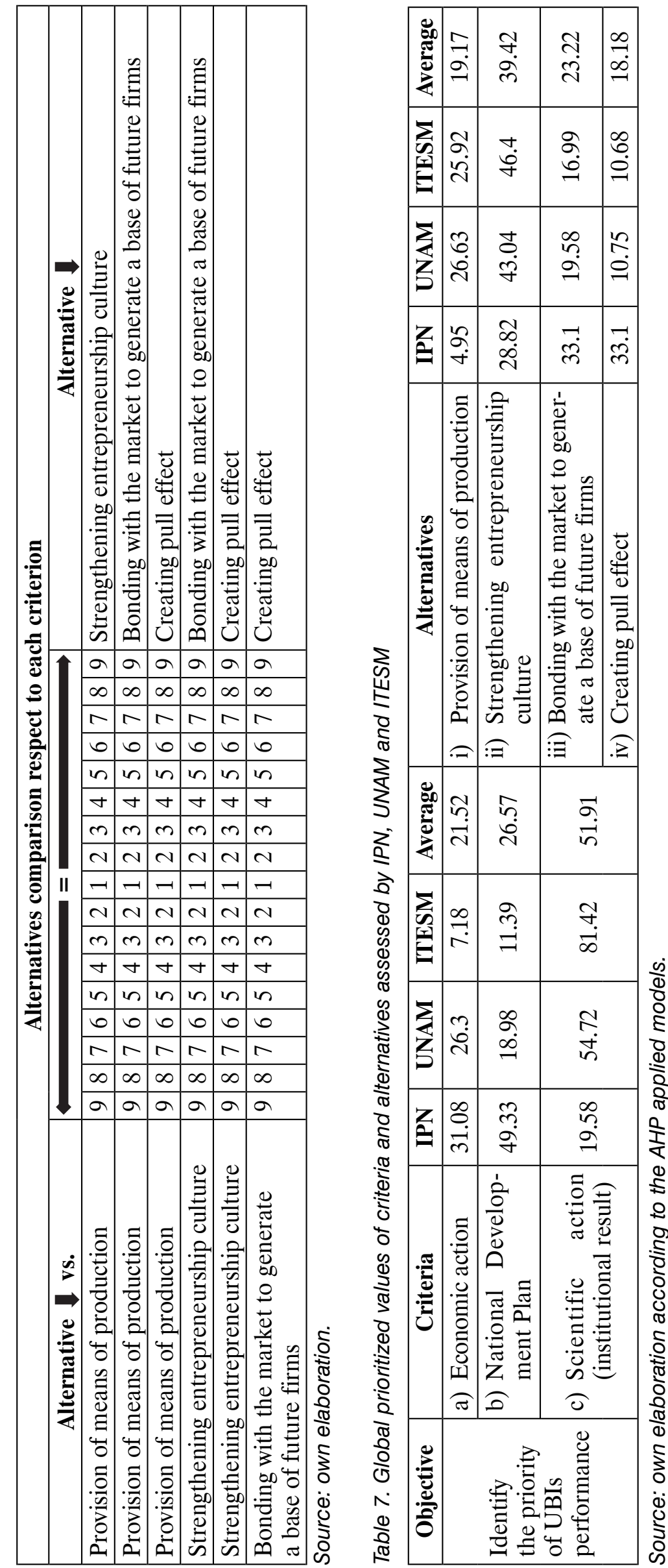




\section{Results}

In order to identify the priorities of UBIs related with the criteria and alternatives pointed out in this work, a pairwise comparison was made and four matrixes for each UBI were obtained. The assessments were applied by using "SuperDecisions" software; the final results were as follows: (figure 4)

The results of the assessment made show that "strengthening entrepreneurship culture" is the priority of the analyzed UBIs and the most important criterion is "scientific action (institutional result)".

\section{Discussion}

The study of the linkages between innovation, entrepreneurship and business incubation needs to be refined with different methods and perspectives. The study of UBIs as intermediate organisms with a tendency to bridge innovation and entrepreneurship has attempted to classify them (Aernoudt, 2004), (Carayannis \& Von Zedtwitz, 2005); nevertheless, there is still a lack of normative criteria of UBIs performance. The results of the assessment made show that "strengthening entrepreneurship culture" is the priority of the studied UBIs and the most important criterion is "scientific action (institutional result)", which means that these UBIs do not act toward reaching regional or national objectives; it could be a negative institutional perspective in Mexico if the public policy of fostering projects with Scientific Innovation was expected to compete at a global level by putting the innovation at the core of entrepreneurship.

Most of the empirical research about business incubation has been carried out with statistics methods, hence it is important to implement other analytical tools, especially when subjective judges could be present, according to (Somsuk \& Laosirihongthong, 2014). An example of such an analytical tool is the AHP, which allows for refining assessments by selecting alternatives that meet the selected criteria in order to reach an objective.

In this work the criteria and alternatives of performance that the three most important Mexican UBIs prioritize were identified; nevertheless, it is important to continue with the analysis of other UBIs in different regions.

\section{Conclusions}

The characterization of the AHP model for UBIs presents results that quantify qualitative factors to know their performance priorities. The three most important UBIs in Mexico do not prioritize providing means of production for the new enterprises; it could reflect the low level of investment. The most important alternative

Figure 4. IPN multicriteria and multialternatives quantified relevance scheme

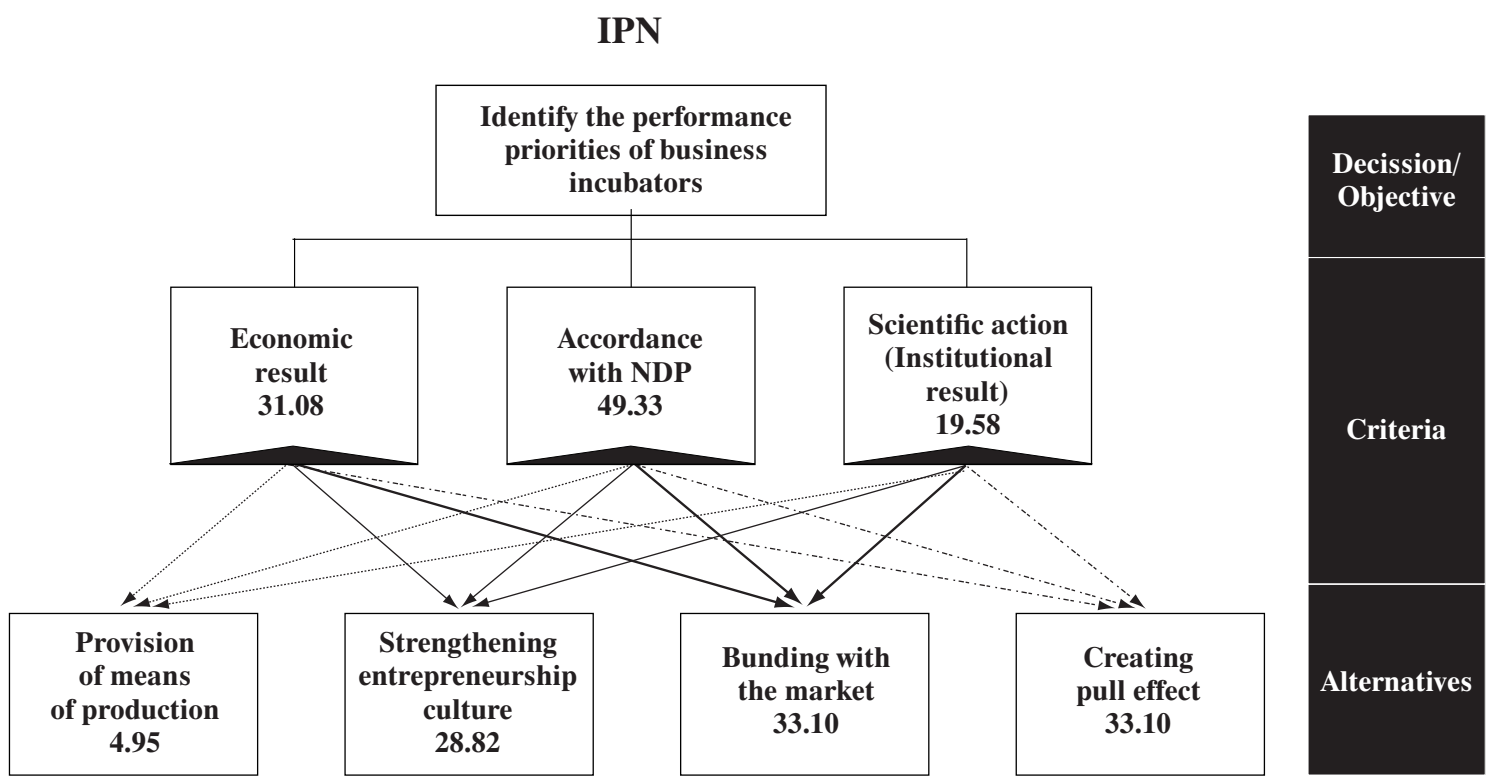

Source: own elaboration according to the results obtained by the AHP model applied to IPN. 
for the UBIs performance is "strengthening the entrepreneurial culture", followed by "bonding with the market to generate a base of future firms". The criterion of "economic action" related with regional economic development and the alternative of "creating pull effect" have the lowest priorities and this indicates that the UBIs we studied have particular objectives, instead of regional or national perspective. A national strategy of UBIs development by establishing global criteria and alternatives could improve the innovation and entrepreneurship policies resources and lead to seeking global, instead of particular, results.

While the evaluated incubators belong to the same category of incubation (UBIs), their criteria of performance are not normative, but they present a similar trend in the prioritization of criteria and alternatives. With the model applied in this research, the assessment of the three most important UBIs in the Mexican economy (IPN, UNAM and ITESM) was performed; however, it is important to continue with studies of other UBIs in different regions toward the establishment of normative UBIs performance that fosters innovation at the core of entrepreneurship.

\section{Footnotes}

1 INADEM is the Spanish abbreviation of National Institute of Entrepreneur which is responsible for the national entrepreneurial programs.

2 The managers of the analyzed UBIs are considered experts in incubation; they agreed to participate in this research as representatives of institutions, not private individuals.

\section{References}

Aernoudt, R. (2004). Incubators: Tool for Entrepreneurship? Small Business Economics, 23(2), 127-135.

Aerts, K., Matthyssens, P. \& Vandenbempt, K. (2007). Critical role and screening practices of European business incubators. Technovation, 27(5), 254-267.

Autio, E., Kenney, M., Mustard, P., Siegel, D. \& Wright, M. (2014). Entrepreneurial innovation: The importance of context. Research Policy, 43(7), 1097-1108.

Azevedo, S. \& Chiappetta, C. (2012). Assessment of business incubators' green performance: A framework and its application to Brazilian cases. Technovation, 32(2), 122-132.

Barbero, J., Casillas, J., Ramos, A. \& Guitar, S. (2012). Revisiting incubation performance how incubator typology affects results. Technological Forecasting \& Social Change, 79(5), 888-902.

Barba-Romero, S. (1996). Manual para la toma de decisiones multicriterio. Santiago de Chile:

Instituto Latinoamericano y del Caribe de Planificación Económica y Social - ILPES.

Bergerk, A. \& Norrman, C. (2008). Incubator best practice: A framework. Technovation, 28(1-2), 20-28.

Bollingtoft, A. \& Ulhoi, J. (2005). The networked business incubator-leveraging entrepreneurial agency? Journal of Business Venturing, 20(2), 265-290.

Brunnel Johan, R. T. (2012). The Evolution of Business Incubators: Comparing demand and supply of business incubation services across different incubator generations. Technovation, 32(2), 110-121

Carayannis, E. \& Gonzalez, E. (2003). Creativity and Innovation = Competitiveness? When, How, and Why. In: L. Shavinina, The International Handbook on Innovation (pp. 587-606). Quebec: Elsevier.

Carayannis, E. \& Von Zedtwitz, M. (2005). Architecting gloCal (global-local), real-virtual incubator networks (G-RVINs) as catalysts and accelerators of entrepreneurship in transitioning and developing economies: lessons learned and best practices from current development and business incubation. Technovation, 25(2), 95-110.

Chang, D. Y. (1996). Applications of the extent analysis method on fuzzy AHP. European Journal of Operational Research, 95(3), 649-655.

Chesbrough, H. W. (2003). Open innovation: The new imperative for creating and profiting from technology. Boston: Harvard Business Press.

Commission of the European Communities (2003). Green Paper Entrepreneurship in Europe. In: Enterprise, Enterprise Publications.

Díaz, R. (2015). INADEM, 23 April (L. Martínez \& J. Muñoz, Interviewers).

Drucker, P. F. (1985). Innovation and Entrepreneurship: Practice and Principles. New York: Harper \& Row.

Etzkowitz, H. \& Leydesdorff, L. (2000). The dynamics of innovation: from National Systems and "Mode 2" to a Triple Helix of university-industry-government relations. Research Policy, 29(2), 109-123.

Evans, D. S. \& Leighton, L (1989). The Determinants of Changes in U.S. Self-Employment. Small Business Economics, 1(2), 111-119.

Freeman, C. (2000). Social inequality, technology, and economic growth. In: S. Wyatt, F. Henwood, N. Miller \& P. Senker, Technology and In/equality: Questioning the Information Society (pp. 149-171). London, UK; New York, USA: Routledge.

Grimaldi, R. \& Grandi, A. (2005). Business incubators and new venture creation: an assessment incubating models. Technovation, 25(2), 111-121. 
Grimaldi, R., Kenney, M., Siegel, D. \& Wright, M. (2011). 30 years after Bayh-Dole: Reassessing academic entrepreneurship. Research Policy, 40(8), 1045-1057.

Howells, J. (2006). Intermediation and the role of intermediaries in innovation. Research Policy, 35(5), 715-728.

Keizer, J. A., Dijkstra, L. \& Halman, J. I. (2002). Explaining innovative efforts of SMEs. An exploratory survey among SMEs in the mechanical and electrical engineering sector in The Netherlands. Technovation, 22(1), 1-13.

Lee, S. S. \& Osteryoung, J. S. (2004). A Comparison of Critical Success Factors for Effective Operations of University Business Incubators in the United States and Korea. Journal of Small Business Management, 42(4), 418-426.

Lee, S., Park, G., Yoon, B. \& Park, J. (2009). Open innovation in SMEs-An intermediated network model. Research Policy, 39(2), 290-300.

Lundvall, B.A. (1992). User-producer relationships, national systems of innovation and internationalisation. In: B.A. Lundvall (ed.), National systems of innovation: Towards a theory of innovation and interactive learning (pp. 45-67).

Lumpkin, G. T. \& Dess, G. (1996). Clarifying The Entrepreneurial Orientation Construct and Linking It to Performance. The Academy of Management Review, 135-72.

Mian, S. (1997). Assessing and managing the university technology business incubator: An integrative framework. Journal of Business Venturing, 12(4), 251-285.

Nelson, R. R. \& Winter, S. G. (1982). An evolutionary theory of economic change. Massachusetts: The Belknap Press of Harvard University Press.

OECD (1999). Business Incubation, International Case Studies. Paris: OECD.

OECD (2004). Promoting entrepreneurship and innovative SMEs in a global economy: towards a more responsible and inclusive globalisation. Paris: OECD Publications.

OECD (2008). Defining Entrepreneurial Activity: Definitions Supporting Frameworks for Data Collection OECD Statistics Working Paper. Sydney: OECD

OECD (2010). The OECD Innovation Strategy: Getting a Head Start on Tomorrow. OECD.

OECD (2013). Science, Technology and Industry Scoreboard 2013. París: OECD.

Penrose, E T. (1959). The Theory of the Growth of the Firm. Oxford, UK: Basil Blackwell.

Pierre-André, J. \& Molina, R. (2012). Una teoría sobre el emprendimiento regional en la economía del conocimiento. Mexico: Pearson.
Radas, S. \& Bozié, L. (2009). The antecedents of SME innovativeness in an emerging transition economy. Technovation, 29(6-7), 438-450.

Radosevic, S. \& Myrzakhmet, M. (2009). Between vision and reality: Promoting innovation through technoparks in an emerging economy. Technovation, 29(10), 645-656.

Reynolds, P. D., Storey, D. J. \& Westhead, P. (1994). Cross-National Comparisons of the Variation in New Firm Formation Rates. Regional Studies, 28(4), 443-456.

Sá, C. \& Lee, H. (2012). Science, business, and innovation: understanding networks in technology-based incubators. $R \& D$ Management, 42(3), 243-253.

Saaty, T. (1977). A Scaling Method for Priorities in Hierarchical Structures. Journal of Mathematical Psychology, 15(3), 234-281.

Schumpeter, J. (1934). Teoría del desenvolvimiento económico, Una investigación sobre ganancias, capital, crédito, interés y ciclo económico. México: Fondo de cultura económica.

Shane, S \& Venkataraman, S. (2000). The Promise of Entrepreneurship as a Field of Research. The Academy of Management Review, 25(1), 217-26.

Skuras, D., Tsegenidi, K. \& Tsekouras, K. (2008). Product innovation and the decision to invest in fixed capital assets: Evidence from an SME survey in six European union member states. Research Policy, 37(10), 1778-1789.

Somsuk, N. \& Laosirihongthong, T. (2014). A fuzzy AHP to prioritize enabling factors for strategic management of university business incubators: Resource-based view. Technological Forecasting \& Social Change, 85, 198-210.

Suk, S. \& Young, O. (2004). A Comparison of Critical Success Factors for Effective Operations of University Business Incubators in the United States and Korea. Journal of Small Business Management, 42(4), 418-426.

Swann, P. G. (2009). The Economics of Innovation. An Introduction. Cheltenham, UK; Northampton, MA, USA: Edward Elgar.

Támasy, C. (2007). Rethinking Technology-Oriented Business Incubators: Developing a Robust Policy Instrument for Entrepreneurship, Innovation, and Regional Development? Growth and Change, 38(3), 460-473.

Teece, D. (1986). Profiting from technological innovation: Implications for integration, collaboration, licensing and public policy. Research Policy, 15(6), 285-305.

Utterback, J. (1994). Mastering the dynamics of innovation. Boston: Harvard Business School.

Wong, P. K., Ho, Y. P. \& Autio, E. (2005). Entrepreneurship, Innovation and Economic Growth: Evidence from GEM data. Small Business Economics, 24(3), 335-350. 